\title{
Sztuka „permanentnego zdziwienia”. Wokół języka symboli w Sztuce znikania Bartka Konopki i Piotra Rosołowskiego
}

\begin{abstract}
„Art disappearance” (2012) ${ }^{2}$ is a film by Bartosz Konopka and Piotr Rosołowski, qualified by the authors of the document, but not entirely located within the traditionally understood documentary ${ }^{3}$. „Art disappearance” combines various genres: classic dokument, found footage and mocumentary. The axis, around which the narrative of the film focuses,
\end{abstract}

1 Agnieszka Kamińska, Katedra Dziennikarstwa i Komunikacji Społecznej, Wydział Nauk Humanistycznych i Społecznych, Uniwersytet SWPS, Polska, akaminska@swps.edu.pl.

2 B. Konopka (reżyseria i scenariusz), P. Rosołowski (reżyseria i scenariusz), „Sztuka znikania” (2012). Film dokumentalny, którego polska premiera odbyła się 19 lipca 2013 roku; premiera światowa 17 maja 2013 r. Historia haitańskiego kapłana voodoo, Amona Frémona, który przyjechał do Polski w 1980 roku. Obserwując wydarzenia stanu wojennego, Amon przywołuje duchy przodków.

3 M. Przylipiak (2000). Poetyka kina dokumentalnego. Gdańsk: Wydawnictwo Uniwersytetu Gdańskiego, s. 36. Przylipiak zaznacza, że zdefiniowanie filmu dokumentalnego nastręcza spore trudności i podaje własną definicję filmu dokumentalnego: „Film dokumentalny to taki film, który prezentuje wycinek świata kompletnego, w którym znaczenia nominalne są tożsame ze źródłowymi, w którym zostaje zachowana indeksalna wierność odtworzenia czasu i przestrzeni w ramach ujęcia, w którym realizatorzy nie ingerują w rzeczywistość przed kamerą albo ingerują i fakt tej ingerencji czynią elementem strukturalnym filmu, albo też ingerują w takim celu, aby przywrócić taki stan tej rzeczywistości, jaki istniał przed pojawieniem się ekipy filmowej, lub też aby wyzwolić prawdę zachowań osób filmowanych, który naśladuje w swojej strukturze konwencjonalne sposoby właściwego człowiekowi porządkowania rzeczywistości, w którym funkcja autoteliczna wobec warsztatu lub tworzywa filmowego, o ile istnieje, to nie może przytłumić i zdominować funkcji przedmiotowej”. 
is in fact a romantic concept of messianism of the Polish nation by Adam Mickiewicz. Less obviously, however, it is inspired by anthropological reflection of Ryszard Kapuscinski. The author analyzed those topics, associations and inspiration appearing in the film which allow the reader to include „Art of disappearing” among the works of the complicated structure of intertextual references.

\section{Keywords:}

anthropology, documentary, voodoo, culture

\section{PERSPEKTYWA ANTROLPOLOGICZNA}

Perspektywa zestawienia materii tak różnej (proza reportażowa i film) kusi możliwościami interpretacyjnymi ze względu na zastosowane punkty widzenia w poddanych analizie utworach. „Heban” Kapuścińskiego to zbiór reportaży napisanych w duchu antropologicznym, w których dojrzały już warsztatowo autor bada kulturową inność. Czyni to z perspektywy reportera wywodzącego się z europejskiego kręgu cywilizacyjnego, choć wcale nie twierdzi, że takie spojrzenie jest najlepsze czy najbardziej wartościowe.

„Sztuka znikania” jest natomiast antropologicznym spojrzeniem na inność à rebours. Jak czytamy na opakowaniu płyty DVD z filmem: „to spojrzenie na czasy socjalizmu oczami przybysza z zupełnie innej kultury”. Głównym bohaterem filmu, którego sposób widzenia Polski starają się odtworzyć twórcy, jest bowiem hungan, czyli haitański kapłan voodoo, który trafił do zupełnie obcego mu kraju w 1980 roku na zaproszenie Jerzego Grotowskiego, mistrza teatru. Amon Frémon pochodził z haitańskiego miasteczka Cazale i był potomkiem polskich legionistów, którzy osiedlili się na Haiti po zakończeniu rewolucji haitańskiej w 1804 roku (Kornak, 2010).

Wspólnym mianownikiem, pozwalającym na badawczą analizę konfrontacji z innością, realizowaną u wymienionych w tytule twórców, jest perspektywa. Konieczne jest tu jednak zastrzeżenie, że antropologiczne zbliżenia z myślą Ryszarda Kapuścińskiego nie zostają - ze strony twórców filmu - wyrażone wprost. Funkcjonują one w tkance tekstowej filmu na poziomie głównie intuicyjnym. O prawdopodobieństwie występowania pewnych pokrewieństw między filmem Konopki i Rosołowskiego a twórczością reportażową Kapuścińskiego można mówić ze względu na to, że autorem komentarza wygłaszanego przez głównego bohatera filmu Amona Fremona jest pisarz Ignacy Karpowicz, znający twórczość 
Kapuścińskiego i wielokrotnie się do niej w różny sposób odwołujący, np. w książce „Nowy kwiat cesarza” (2007).

Antropologia jest dziedziną polegającą na obserwacji innej kultury, gromadzeniu faktów z jej przejawów i ich analizowaniu4. Burszta pisze o antropologii, że jest to „powołanie do permanentnego zdziwienia”:

\begin{abstract}
„Wydaje mi się, że jedna z wielu możliwych definicji antropologii mogłaby brzmieć tak: jest to powołanie do permanentnego zdziwienia człowiekiem w objęciach owego niewidzialnego tworu zwanego kulturą; jest to powołanie, które nie zadowala się jedynie naukową analizą i tłumaczeniem, ale zmusza do zapisywania wrażeń, spostrzeżeń i fascynacji w formie opowieści niestandardowych, z wyraźnie zaznaczoną autorską sygnaturą” (Burszta, 2004, s. 178-179).
\end{abstract}

Antropologia sięgnęła po środki dotychczas zarezerwowane wyłącznie dla literatury. Refleksyjność, metafora, parabola - doskonale zaczęły się sprawdzać w nowym obszarze użycia. Kołodziejczyk (2002, s. 63) proponuje, by autorefleksyjność antropologii potraktować jako wewnętrzną cechę dyscypliny, która stanęła w obliczu konieczności otwarcia się na Inność. U podstaw tej zmiany leży zrozumienie, że obcość nie jest z góry nadana i przypisana określonym kulturom. Jest ona jedynie epistemologicznym założeniem. Podobnie jak Inność, zależy od punktu patrzenia na świat, co pozwala mówić o relatywizmie kulturowym. W uproszczeniu można stwierdzić, że oznacza on po prostu uznanie wszystkich kultur za równe:

„Każda kultura to samoistna „monada”, metafizyczny wszechświat sam w sobie. Ludzkość jest zorganizowana w tysiące takich monad rozproszonych po ziemi w postaci różniących się języków, społeczeństw, jednostek wreszcie. Każdy z nas tak naprawdę żyje tylko w jednej z takich monad i z jej „wnętrza” przygląda się i ocenia konkurencyjne sposoby radzenia sobie z życiem. Z ta-

4 Pojęcie antropologii należy rozumieć szeroko. Samo słowo „antropologia” zbudowane jest z greckiego antropos (istota ludzka) i logos (słowo), co można w uproszczeniu tłumaczyć jako „badanie ludzkości”. W antropologii trzeba jednak wyróżnić kilka dziedzin dotyczących badań nad istotą ludzką. Wśród nich zasadnicze znaczenie dla niniejszej pracy ma antropologia kulturowa, czyli nauka badająca wzory życia niedawnych czy współczesnych ludów. Dla niniejszej pracy najistotniejsza wydaje się konkluzja, że w gruncie rzeczy antropologia kulturowa to „dyscyplina zrodzona z potrzeby poznawania i oswajania światów kulturowych zewnętrznych wobec całości zwanej „kulturą europejską”. 
kiego stanowiska wyciąga się niekiedy wniosek, że nie ma ponadhistorycznych czy transcendentalnych kryteriów pozwalających obiektywnie oceniać różne kulturowe tradycje” (Burszta, 2004, s. 193).

Współcześnie antropologia i literatura doskonale się uzupełniają. Pierwsza daje literaturze pole do eksperymentowania na zjawiskach kulturowych, ta druga odwzajemnia się, oferując repozytorium środków. Ostatecznie obie angażują się w tematy związane z poszukiwaniem przez bohaterów własnej tożsamości, tropieniem odległych korzeni, stwarzaniem pozorów domu w różnych zakątkach ziemi. I antropologia, i literatura angażują się:

„[...] w pytania pozornie typowe dla antropologii - o kulturową tożsamość i autentyczność kultury, o różnice między egzotyką a innością, o zaprawę scalającą konstrukcje społeczne; wreszcie o to, kto mówi i kto ma prawo mówić w imieniu innego, reprezentować inność, określać swój przedmiot badań jako inność” (Burszta, Kuligowski, 2005, s. 68).

Powstają dzięki temu zupełnie nowe jakości, na przykład literatura postkolonialna czy, bliska jej, wielokulturowa.

\section{REPORTAŻ ESEISTYCZNY}

Ryszard Kapuściński jest jednym z pierwszych, którzy się porwali na nowe obszary antropologii. Dostrzegł, że stare metody opisu już nie przystają do dekolonizującego się świata. Stąd, na własne potrzeby stworzył „reportaż eseistyczny”, wręcz idealne zastosowanie modelu antropologii z pogranicza literatury (lub na odwrót - zależy od punktu widzenia). Obiektywny ogląd reporterski wzbogacił subiektywnym punktem widzenia człowieka odwołującego się do całego bagażu swego życiowego doświadczenia.

Kapuściński jest wszakże świadomy tego, że konfrontacji z nie-europejskimi światami dokonuje z pozycji Europejczyka. Wie, że nie jest możliwe całkowite „wykorzenienie” się z własnej, przyrodzonej kultury. Reporter żywił przekonanie, że to, czego bezpośrednio doznajemy w świecie, wiąże się ściśle z doświadczeniami w życiu prywatnym i życiu wewnętrznym, intelektualnym. Treści te są głęboko zaszyfrowane. Klucz do tego kodu leży w naszej kieszeni. „Wozimy go zawsze do obcych krajów [...] Znamy jego schemat, ale nie sposób uprzystępnić go innym” (Kapuściński, 1962, s. 78). Ryszard Kapuściński wielokrotnie określa 
swoją twórczość jako „pisaną w zasadzie w formule antropologicznej” (2003, s. 56).

U Kapuścińskiego - pisarza, literata, wreszcie reportera - ogląd kultury obcej nigdy nie będzie więc czysto obiektywną relacją o faktach. Można nawet zaryzykować stwierdzenie, że gdyby nie doświadczenie Europejczyka w Kapuścińskim, nie byłoby twórczości Kapuścińskiego. Czy jako Afrykańczyk zdziwiłby się upałem na Czarnym Lądzie? Albo jako Hindus - czyż nie zabrałby swojego własnego łóżka do pociągu? To temu zdumieniu obcymi światami zawdzięczamy „Heban” (1998), „Podróże z Herodotem” (2004), „Imperium” (1993). Jest ono możliwe tylko z przyrodzonej Kapuścińskiemu perspektywy europocentrycznej - mniej lub bardziej świadomej. W „Sztuce znikania” analogiczną perspektywę, ale w wydaniu à rebours, przyjmie główny bohater Amon.

\section{PUNKT WIDZENIA}

Warto tu przy okazji wskazać, kim jest ów czytelnik Kapuścińskiego, gdyż będzie to zagadnienie istotne także w konstrukcji metatekstowej filmu Konopki i Rosołowskiego. Czermińska (2003, s. 12) wskazuje na co najmniej trzy możliwe konfiguracje, w jakich uobecnia się antropologiczny punkt widzenia podczas tworzenia wypowiedzi w sytuacji zetknięcia się różnych kręgów kulturowych. Wśród różnych wariantów najbardziej interesujący jest ten, gdy „autor mówi o świecie innym, by przedstawić go czytelnikom z własnej wspólnoty, którzy nie mieli okazji poznać odmiennego kręgu kulturowego” (Czermińska, 2003, s. 12). Oznacza to sytuację, gdy wypowiedź narracyjna powstaje w relacji „swój o tym, co inne do swoich (tożsamość nadawcy i odbiorcy, inność przedmiotu”.

W przypadku filmu „Sztuka znikania” zabieg ten, choć pozornie „na serio”, tak jak i cały film jest w swej konstrukcji oczkiem puszczonym do widza. Autorzy filmu grają z nim w intelektualną zgadywankę badając, czy się odbiorca zorientuje, czy przeciwnie - wszystko weźmie na poważnie. Bohater „Sztuki znikania” pozornie bowiem mówi „o innym do swoich”, ale oczywiste jest, że owi „swoi” nigdy tego filmu nie zobaczą. Zatem de facto mówi do tych innych, ale używa własnego aparatu pojęciowego, z własnej kultury i mentalności się wywodzącego. Nawet nie stara się przyjąć perspektywy tych, do których przybył.

Amon Frémon ogląda polską rzeczywistość PRL oczami człowieka z kompletnie odmiennej kultury i kręgu mentalnego. Styka się z polską symboliką, którą próbuje zrozumieć i przetłumaczyć sobie na swój własny sposób. Dzięki temu zabiegowi polski odbiorca filmu widzi tak dobrze mu znane wydarzenia 
w innym kontekście, tworząc z tego zderzenia odmiennych perspektyw nowe wartości i na nowo odczytując własną kulturę. Polska historia i symbolika stają się dla wyrosłego w swojej kulturze Polaka całkowitym zaskoczeniem. Przegląda się on w tym zwierciadle zdziwiony, z niedowierzaniem, że tak odległe skojarzenia Haitańczyka są tak głęboko trafne.

\section{W PRZEKŁADZIE Z KULTURY NA KULTURĘ. POLSKIE OBRZĘDY LUDOWE A HAITAŃSKIE RYTUAŁY VOODOO}

W „Sztuce znikania” w sposób szczególny unaocznia się refleksja Ryszarda Kapuścińskiego o leżącym w kieszeni podróżującego do obcych kultur „kluczu do szyfru” obcości. Tym kluczem stara się wędrowiec otwierać wszystkie kody językowe, symboliczne czy mentalne. Dlatego także bohater filmu Konopki i Rosołowskiego do odczytania obcych mu znaków używa swojego aparatu pojęciowego. Swojego szyfru, który przywiózł w kieszeni z Haiti. Już pierwsze minuty filmu nawiązują do twórczości polskiego reportażysty, który tak rozpoczyna „Heban”, swoją antropologiczną opowieść o Afryce:

„Przede wszystkim rzuca się w oczy światło. Wszędzie - światło. Wszędzie - jasno. Wszędzie - słońce. Jeszcze wczoraj, ociekający deszczem, jesienny Londyn. Ociekający deszczem samolot. Zimny wiatr i ciemność. A tu, od rana całe lotnisko w słońcu, my wszyscy - w słońcu [...] Samolot gwałtownie wyrywa nas ze śniegu i mrozu i jeszcze tego samego dnia rzuca w rozpaloną otchłań tropiku. Nagle, ledwie przetarliśmy oczy, jesteśmy wewnątrz wilgotnego piekła. Od razu zaczynamy się pocić” (Kapuściński, 1998, s. 5).

Negatywem tej sytuacji jest scena z filmu, w której Amon - wyrwany z rozgrzanej słońcem rodzinnej wyspy - ląduje w zimnej, ponurej, deszczowej i ciemnej Warszawie, stolicy kraju na Północy: „Wszystko tu wyglądało inaczej. Nawet deszcz padał głośniej, jak w kraju ogłuchłych ludzi”. W przeciwieństwie jednak do Kapuścińskiego, Amon nie doznaje szoku w zderzeniu z odmiennością, tak jak polski reporter w Afryce. Sytuacja nowości jest dla niego fazą liminalną, jest kulturową (i biologiczną) inicjacją:

„Nigdy wcześniej nie leciałem samolotem i nie widziałem na raz tylu białych. Byłem podniecony. Drżały mi ręce i nogi. Drżenie przeszło na samolot. Cały samolot trząsł się jak w gorączce. Fotele, ściany, niebo, wszystko. Zrozumia- 
łem, że otrząsam się z nieprawdziwej skóry. Stawałem się jak moi pradziadowie - biały. Im bliżej byłem legendarnej „Laba laPolòy”, tym bardziej byłem Polakiem i Haitańczykiem też”.

Amon Frémon, już z racji swojego pochodzenia, należy sam w sobie do bytów liminalnych, czyli - jak chce Turner (2005, s. 122) - „ni to, ni owo: nie są ani tu, ani tam, ale znajdują się między stanami definiowanymi i ustanawianymi przez prawo, obyczaj, konwencje i ceremoniały”. Nieokreśloność statusu Amona polega na tym, że jako Haitańczyk jest hunganem, czyli kapłanem voodoo, zaś dzięki domieszce krwi polskiej jako jedyny czuje się w mocy, by uwolnić dusze swoich białych braci spod władzy złych loa (duchów). Jedność obydwu stanów odnajduje Amon w świętych rytuałach, których podobieństwo - pomimo różnicy mentalnej i kulturowej - dostrzega.

Voodoo ma swoje korzenie w dalekiej przeszłości Afryki, skąd na Haiti przywędrowali czarni niewolnicy wraz ze swoimi wierzeniami. Z biegiem lat obrzędy afrykańskie się modyfikowały, przejmując liczne elementy z innych religii, między innymi chrześcijaństwa. Na bliskie związki w rytualności pomiędzy polskimi, ludowymi obrzędami a ceremoniami haitańskimi, zwracał uwagę Leszek Kolankiewicz. Wspólnym mianownikiem jest tu pojęcie „ducha”, które nabrało szczególnego znaczenia w twórczości romantycznej, przede wszystkim zaś w „Dziadach” Adama Mickiewicza, którego Kolankiewicz nazywa „reżyserem świętokradczych obrzędów. Tyle że nie prywatnych, lecz - kulturowych” (Kolankiewicz, 1999, s. 224). Zdaniem Kolankiewicza „Dziady” Mickiewicza dlatego rozgrywają się poza cerkwią, poza dworem, bo ich obrzędowość wymaga terytorium zdominowanego przez wyobraźnię. Sam Mickiewicz w paryskich prelekcjach tłumaczył, co dla niego znaczy słowo „duch”: „U Słowian duch jest tym, co we wszystkich krajach lud dotąd zwykł nazywać «duchem», kiedy ktoś mówi, że «widział ducha», «rozmawiał z duchami»” (Kolankiewicz, 1999, s. 227). Romantyzm z jego uwielbieniem i wiarą w duchowość, jest najbliższy kulturowej i mentalnej postawie haitańskiego kapłana:

„Nie ma co się łudzić: we Francji, obojętnie, gdzie miałaby się ona znajdować, Dziadów nie zrozumieją, mogliby natomiast - porównanie jest Miłosza z rozmów „Polityki” - w Afryce. Dlatego że - uważa Miłosz - Mickiewicz odkrył struktury doświadczenia równie stare, jak te animistyczne, do dziś religijnie nośne w Afryce. Toteż my, z owym świętem „poza” [...] może zawsze będziemy w oczach Europy ludźmi z hebanem pod skórą” (Kolankiewicz, 1999, s. 227). 
Przywołajmy tu wątek domieszki krwi polskiej w żyłach Amona, haitańskiego kapłana voodoo, który przyleciał do Polski, kraju swoich przodków, i który w samolocie doznał rytualnej inicjacji, przejścia w fazę liminalną („Stawałem się jak moi pradziadowie - biały. Im bliżej byłem legendarnej „Laba laPolòy”, tym bardziej byłem Polakiem i Haitańczykiem też”).

Dla niniejszych rozważań istotna wydaje się dalsza myśl Kolankiewicza, który konsekwentnie buduje analogie pomiędzy polską i afrykańską mentalnością. Pomocne okazuje się tu przywołanie refleksji Ryszarda Kapuścińskiego, na którego związki z filmem „Sztuka znikania” Bartosza Konopki i Piotra Rosołowskiego już zostały wyżej wspomniane:

„Czy nie powinniśmy spróbować zrozumieć Afryki, żeby móc pełniej pojąć - siebie samych? «Duchowy świat Afrykanina (świadomy jestem, że używając tego określenia, bardzo upraszczam) jest bogaty i złożony, a jego życie wewnętrzne przenika głęboka religijność». To Ryszard Kapuściński z Hebanu, jego książki może najpiękniejszej, książki życia. Kapuściński wylicza i charakteryzuje światy, w których zwykł żyć Afrykanin [...] Jak niegdyś Stanisław Vincenz odnalazł na wysokiej połoninie kulturę będącą środowiskiem Dziadów i w huculszczyźnie zobaczył nawet starożytną Grecję, tak teraz Ryszard Kapuściński może nam pomóc odkryć i jedną, i drugą jeszcze dalej, już chyba najdalej; w pustyni i w puszczy” (Kolankiewicz, 1999, s. 228).

Amon odwiedza Polskę w czasie, gdy społeczeństwo tkwi w uścisku komunistycznej władzy. Podczas swojej podróży widzi obrazy zupełnie dla niego niezrozumiałe, na przykład długie kolejki przed drzwiami sklepów. Mówi: „Dużo rzeczy mnie dziwiło. Nie rozumiałem, dlaczego dywany są takie ważne [...] Czasem potrafili godzinami stać w miejscu i czekać bez słowa”. Jego zdziwienie budzi także wielki, strzelisty gmach, przypominający mu budowane na Haiti grobowce. Tylko po co w nim okna - pyta zdziwiony przybysz z innej kultury:

„W środku miasta wzniesiono ogromny budynek. Nie można było go nie widzieć. Przypominał mi nagrobki, które wznosimy na Haiti. Ale my nie wstawiamy w nie okien. Okna w grobowcu to bardzo niedobry pomysł”.

Mowa oczywiście o Pałacu Kultury i Nauki, który widzowie mają przed oczyma na ekranie, jako ilustrację powyższych słów. Również słynne w PRL uroczystości dożynkowe na Stadionie Narodowym przekłada sobie Amon na swój 
własny kod kulturowy. Słynne i rozpoznawalne przez większość Polaków ujęcia obchodów w 1968 roku z udziałem Władysława Gomułki, relacjonuje Haitańczyk w ten sposób:

\begin{abstract}
„Podczas mojej podróży trafiłem na ceremonię, w której kobiety oddawały hołd grupie kapłanów. Na trybunie stali starcy i oglądali spektakl na swoją cześć. Przed nimi młode kobiety składały ofiary i odprawiały rytualne tańce. Starcom sprawiało to radość, widać to było w ich oczach, to dla nich była cała ta ceremonia”.
\end{abstract}

Bohater filmu „Sztuka znikania” Amon Frémon chociaż nie rozumie języka swoich białych braci, to jednak czuje zło, które ich niewoli i pogrąża. Perspektywa Innego pozwala mu zarazem dostrzec i usłyszeć rzeczy, do których nie miałby dostępu, gdyby odbierał je poprzez racjonalizm, a więc za pomocą „mędrca szkiełka i oka”: „Zbierali się żeby być razem, ale tak naprawdę każdy z nich był i stał osobno. Chciałem być z nimi, ale oni się odsuwali. Oni nie chcieli być ze mną. Oni nawet nie chcieli być ze sobą”. Amon w swojej mocy poszukuje więc rytuału, który uwolniłby ich dusze z więzów guede (duchów śmierci). Mówi:

„Jak mogłem służyć moim rodakom z Polski? Jak mogłem zatrzymać ich ciągłe zjeżdżanie w sen? Skoro tak wygląda świat ludzi, to jak wygląda świat duchów w moim pierwszym kraju? Ile oczu noszą tutejsze duchy? Gdzie mieszkają? Szukałem Haiti w Polsce. Czegoś wspólnego. Prochów. Cmentarza. Zmarłych”.

W filmie moment przełomowy następuje z chwilą, gdy Amon, haitański kapłan (hungan), trafia na cmentarz, gdzie w jakiejś nieoznaczonej przestrzeni i czasie bierze udział w magicznym obrzędzie Dziadów. Dzieje się tak, ponieważ jego haitańskie zdolności pozwoliły mu odnaleźć przewodnika:

„Wiatr podpowiadał mi gdzie szukać. Czasem wystarczy jeden krok. Poczułem moc. Pośród grobów zobaczyłem znak Barona Samedi. Wołały mnie różne demony. Aż na Skrzyżowaniu odnalazłem przewodnika. Był kiedyś potężnym hunganem. Odprawiał wielki obrzęd, złożył ofiary, ale nie zdołał pokonać guede, duchów śmierci. Chciał je przebłagać, żeby zatrzymały cierpienia Polaków, ale przegrał”. 
Kim jest ów przewodnik, którego spotkał Amon, wyjaśnia Kolankiewicz, który opisał swoją niegdysiejszą przygodę z oprowadzaniem po Warszawie kreolskiej wycieczki z Haiti:

„Kiedy prowadziłem Traktem Królewskim grupę [...] spostrzegłem, że nic nie łapią z polskiej historii i kultury. Byłem już zrezygnowany, gdy na Trębackiej koło Pałacu Wesslów olśniło mnie - po drugiej stronie Krakowskiego Przedmieścia wieszcz na cokole. «Tam stoi pomnik Adama Mickiewicza, poety, który w dziewiętnastym wieku napisał Dziady, sztukę dla teatru, ale tak naprawdę...» - tu zawiesiłem głos i palnąłem, zaskakując nawet samego siebie - «rekonstrukcję obrzędu woduistycznego, jaki dawniej odprawiało się na wsi». Stanęli. Patrzyli przyjaźnie na pomnik i uznaniem kiwali głowami... «był wieszczem, a w Polsce to jak hungan». Na Haiti hungan sprawuje pieczę nad duchami i ma rząd dusz" (Kolankiewicz, 2007, s. 132).

Kluczem do rytuału odkupienia białych braci jest nagłe poczucie jedności, którego doznaje Amon, kapłan, hungan, podczas wydarzeń w Stoczni Gdańskiej. To, że jest to Sierpień `80, a rzecz dzieje się w Stoczni, wiedzą polscy widzowie. $\mathrm{Z}$ monologu Amona wcale nie wynika, że wie, gdzie się znajduje. Wciąż patrzy na polską rzeczywistość oczyma przybysza, ale przybysza „uprzywilejowanego” mocą hungana:

\begin{abstract}
„Wreszcie zobaczyłem ich razem. Innych niż zawsze. Na bramie powiesili świętych. Zobaczyłem Erzulie, boginię, którą polscy legioniści przywieźli na Haiti. Erzulie Dantor, której składamy w ofierze rum i mocne papierosy. Czarną panią z trzema ranami na policzku. Polacy nazywali ją swoją królową. Jej imienia wzywali. Ktoś złapał mnie za rękę. Byłem razem z nimi. I wtedy Erzulie weszła we mnie”.
\end{abstract}

W języku voodoo oznacza to „opętanie”, czyli wejście w trans, podczas którego loa (duchy) opanowują jedną lub więcej osób (Zwoliński, 2011, s. 113). Określa się ten moment często jako „dosiadanie” lub „ujeżdżanie swojego konia” przez duchy (Zwoliński, 2011, s. 113). W tym stanie loa może przemawiać do zebranych, a sam „opętany” także staje sie przez to na chwilę bogiem, doznając wtajemniczenia w sprawy nie z tego świata. „Świętym opętaniem” nazwała obrzęd polskich, ludowych Dziadów Maria Janion, zatem refleksja Kolankiewicza o szczególnym 
porozumieniu między polską a afrykańską duchowością wydaje się w tym kontekście jak najbardziej słuszna (Kolankiewicz, 1999, s. 221).

Symbole zrozumiałe dla Polaka, Amon tłumaczy na swój język. W warstwie wizualnej filmu widzimy Lecha Wałęsę, unoszonego na rękach robotników. Amon Fremon mówi: „Zobaczyłem kapłana, którego teraz dosiadła Erzulie. Wyglądał jak zwykły człowiek. Jak Dutty Boukman pod Świętym Drzewem 200 lat temu. Zaczynałem rozumieć”. Okazuje się jednak, że jego rozumienie obserwowanych wydarzeń wcale nie jest złe czy błędne. Przeciwnie - ma swoją „duchową” logikę. Amon siłą swojej mocy wiedział, co się wydarzy. Wiedział, że białemu kapłanowi, w którego także weszła Erzulie, grozi wielkie niebezpieczeństwo. Przede wszystkim guede, czyli duchy śmierci:

„Próbowałem do niego podejść i go ostrzec. Uważaj, duchy śmierci nie poddadzą się. Uważaj, stanie się coś złego. Nie pozwolili mi z nim porozmawiać. Odepchnęli mnie. Myśleli, że się wzruszyłem. Ktoś poklepał mnie po ramieniu. A ja po prostu byłem przerażony. Wiedziałem, co im grozi. Nie słyszałem już żadnych słów. Myślałem tylko o tym, co mogę zrobić. Myślałem tylko o tym, co ma nadejść [...] Kapłan Erzulie zniknął bez śladu. Nastała długa, zimna noc.

W czasie tej „długiej, zimnej nocy” rządy przejęły - w rozumieniu Amona - siły ciemności. W warstwie wizualnej filmu następują po sobie kadry z archiwalnych nagrań z okresu stanu wojennego. Amon opisuje zimę stulecia sobie właściwym językiem: „Przyszła zima jakiej nigdy nie widziałem. Z nieba leciała zła, biała woda. Woda guede, woda niegasząca pragnienia. Woda, która parzy usta. Nie wsiąkała w ziemię, tylko leżała jak piasek. Ludzie nie mogli się poruszać. Zimny piasek uwięził ich w domach”.

Dla bohatera filmu sygnałem zdecydowanie wzywającym go do użycia mocy kapłana voodoo są armie zombie, które wyprowadziły na polskie ulice siły ciemności: „Prości ludzie bardzo boją się zombie, bo to znaczy, że w okolicy jest kapłan, który potrafi kraść dusze”. Kiedy Amon wymawia te słowa, przed oczyma widzów pojawia się postać generała Wojciecha Jaruzelskiego w słynnym ujęciu z chwili ogłaszania stanu wojennego. Kiedy zaś mowa jest o „armiach zombie” - na ekranach widać biegnące, w pełni uzbrojone zastępy ZOMO.

Nazwanie oddziałów ZOMO określeniem „zombie” jest konsekwencją istnienia „kapłana, który potrafi kraść dusze”. Zwrócić należy przy tym uwagę na dokumentalny charakter filmu. Autorzy filmu sięgnęli w związku z tym po zakorzenione w wierzeniach i rytuałach voodoo przekazy o istnieniu zombie, czyli „żywych trupów”: 
„Unikatowym rytuałem voodoo jest ceremonia stworzenia zombie [...] Opiera się na przekonaniu, że dusze ludzi można ukraść. Zombie po śmierci zostaje ożywione przez bokora i musi mu ślepo służyć. Bokor potrafi bowiem zadać mu truciznę, która powoduje rodzaj śpiączki, po czym podaje mu antidotum [...] Po pewnym czasie czarownik wydobywa ofiarę z grobu i ożywia za pomocą mikstury zwanej „ogórkiem zombie”. Zdezorientowana, przerażona i znajdująca się na skraju wyczerpania psychicznego i fizycznego ofiara otrzymuje nowe imię i staje się niewolnikiem czarownika [...] W podaniach voodoo zombie pozostają umarłymi bez duszy, którzy zostali wskrzeszeni z grobu, by odtąd być zmuszonymi ślepo służyć swemu panu [...] Istnieje też tradycja „duchowych zombie”, polegająca na tym, że czarownik uzyskuje kontrolę nad duszą zmarłego. Ów zombie astral, podobnie jak jego fizyczny odpowiednik, staje się całkowicie posłuszny czarownikowi” (Kolankiewicz, 1999, s. 119-120).

Bartosz Konopka i Piotr Rosołowski zestawiając dwa porządki kulturowe uzyskali niespotykany efekt interpretacyjny. Równie oryginalnie brzmią wersy z „Dziadów” Adama Mickiewicza jako ilustracja rytuału „,wypędzania z Polaków złych loa”. W poecie znalazł bowiem Amon Frémon przewodnika, który wyznacza mu kierunek wykorzystania wszystkich dostępnych mu mocy: „Zrozumiałem, że Erzulie każe mi spłacić stary dług krwi. Musiałem wypędzić z Polaków złe loa. Musiałem użyć wszystkich swoich mocy, polskich i haitańskich zaklęć”. W „Dziadach” Mickiewicza odnajduje Amon (a tym samym autorzy „Sztuki znikania”) znany mu z Haiti „obrzędowy rytm świętowań”:

„W tym rytmie obecny jest specyficzny rytm egzystencji [...] że podtrzymuje obecność duchów zmarłych, bez których społeczność nie będzie w pełni sobą. Taki obrzędowy rytm świętowań znała starożytna Grecja i długo europejska kultura ludowa o starożytnym rodowodzie. Dziś pamięta go jeszcze Afryka. I dlatego stoi ona bliżej niż my zarówno naszych Dziadów, jak greckiego dionizyzmu” (Kolankiewicz, 1999, s. 228).

W czasach Mickiewicza „wolność ludu sprowadzała się niejako tylko do wolności obcowania ze zmarłymi” (Janion, 2007, s. 55), dlatego i Amon Frémon widzi możliwość wykupienia białych braci z niewoli złych duchów tylko poprzez obrzęd duchowy. Na ekranie widać pogrążony w mroku cmentarz, kapłana wznoszącego ręce i słychać przy tym głos Amona-hungana, wypowiadającego dobrze znane Polakom słowa: 
„Ciemno wszędzie, głucho wszędzie, Co to będzie, co to będzie?

Ledwie jedną myśl rozniecisz, Już czekają w milczeniu, jak gromu żywioły,

Tak czekają twej myśli szatan i anioły: Czy ty w piekło uderzysz,

Czy w niebo zaświecisz.

Niech ludzie będą dla mnie jak myśli i słowa,

Z których gdy zechcę pieśni wiąże się budowa.

Ludzie każdy z was mógłby samotny, więziony,

Myślą i wiarą zwalać i podźwigać trony”.

Idea odkupienia i ofiary to podwaliny mesjanizmu, fundamentu polskiego romantyzmu (Janion, 2007, s. 65). Z kolei ich sensem jest przemiana, bo grób oznacza odrodzenie. I tak jak Gustaw przemienia się w Konrada (choć pozostaje wciąż tym samym), tak Amon z haitańskiego hungana przemienia się białego, choć z pozoru jest tym samym człowiekiem:

„Ta ceremonia w Polsce była największym wyzwaniem, przed którym postawiła mnie Erzulie. Udało mi się, ale stałem się kimś innym. Nikt mnie nie poznawał. Dzieci wołały za mną „blanc”, czyli biały. Starzy znajomi mówili, że nie przypominam siebie. Stałem się białym cieniem. Nie odprawiałem już ceremonii, nie rozmawiałem z duchami. Mój peristil był pusty. Byłem sam. Podczas ceremonii w Polsce musiałem poświęcić moją moc hungana i duszę. Złożyłem je w ofierze. Tego chciała ode mnie Erzulie. Umarłem jako hungan. Ofiara została przyjęta”.

Ostatnie słowa Amona autorzy filmu zilustrowali ujęciem płonącego drzewa, które symbolizuje przyjęcie ofiary, odkupienie, wyzwolenie spod władzy złych duchów i przemianę.

Haitański kapłan zapłacił wysoką cenę za rytuał Dziadów, odprawiony w Polsce. Po powrocie na Haiti, stał się obcy dla swoich, odszedł niewiadomo dokąd, ani niewiadomo jak. Nic po nim nie zostało, prócz śladu po jego ulubionym drzewie, uznawanym za święte. Przeistoczył się w „białego”, ale nie było to dla niego źródłem pociechy ani wyznacznikiem wyższego statusu. W tym kontekście ciekawe wydaje się spostrzeżenie Kapuścińskiego, który w „Buszu po polsku” pisze:

„Nana z Mpango był kościsty i łysy, o wąskiej sudańskiej wardze. Kofi przedstawił siebie, szofera i mnie. Wyjaśnił, skąd jestem, i że mają mnie traktować jako przyjaciela. - Ja go znam - powiedział - to Afrykańczyk. 
Jest to najwyższy komplement, jaki może spotkać Europejczyka. Wszędzie otwierają mu wtedy drzwi” (Kapuściński, 1962, s. 75).

Nie przypadkiem reżyserzy filmu uznali rytuał Dziadów za najważniejszą scenę w filmie. Po pierwsze - jak już było wspomniane - w kulturze ludowej okresu romantyzmu postrzegano je za jedyny dający prawdziwy kontakt z zaświatami, a tym samym (za sprawą bliskości zmarłych i grobów) także za posiadający największą moc magiczną. „Dziady” to także dzieło Mickiewicza o symbolicznym dla polskiej kultury wydźwięku. „Dziady” wreszcie to kolejne spektakle, odgrywane na polskiej scenie z powodzeniem przez dziesięciolecia.

Tę najsłynniejszą inscenizację, o kapitalnym dla polskiego społeczeństwa znaczeniu, zrealizował Kazimierz Dejmek w 1967 roku w Teatrze Narodowym. Kolankiewicz cytując Elżbietę Morawiec podkreśla, że spektakl odebrany był jako „chrześcijański rytuał”, zaś Zbigniew Raszewski pisał o „misterium ludowym, w którego ramach dał się słyszeć przejmujący krzyk o wolność” (Kolankiewicz, 1999, s. 217). O rytualnym charakterze „Dziadów” Dejmka mówił sam Gustaw Holoubek, aktor, dzięki którego grze spektakl nabrał tak porażającej siły społecznego oddziaływania: „kiedy w Dziadach Dejmka wchodziło się na scenę, wchodziło się w owych dniach w czas nadnaturalny i przestrzeń całkowicie niezgodną z wymiarami zarówno sceny Teatru Narodowego, jak i jego sali [...] Nie, inspiracja właściwie płynęła zewsząd”, a Kolankiewicz dopowiada myśl Holoubka twierdząc, że płynęła ona „z jakiejś czasoprzestrzeni mitycznej - mitu narodowego" (Kolankiewicz, 1999, s. 218).

Dalej opowiada Holoubek o utracie kontroli nad sobą, a więc rodzaju transu czy opętania, które stało się - w „Sztuce znikania” - przecież też udziałem Amona, kapłana voodoo, gdy odprawiał obrzęd ratujący Polaków z mocy złych loa:

„[...] w „Dziadach”, pod wpływem owej przemożnej inspiracji, utracił kontrolę nad postacią i jej oddziaływaniem. Nawet, jeśli było to skutkiem jakiejś historycznej kondensacji atmosfery społecznej, to kondensacja ta dokonała się według reguł rządzących strukturami mitycznymi: dla wykonawców «trwało wdanie się w sferę całkowicie irracjonalną, podniosłą, niezmiernie wzruszającą [...] Żaden człowiek nie może unieść ciężaru ponad swoje siły! Chyba że się wyizoluje od rzeczywistości, skoncentruje tak, że dotknie go Anioł! To nie jest sprawa techniki, ale swoistego cudu [...] Poczułem się jak uniesiony na skrzydłach czegoś niewidzialnego. Czułem się nieomal fizycznie oderwany od podłogi»” (Kolankiewicz, 1999, s. 219). 
Tu reżyserzy „Sztuki znikania” puszczają do widzów filmu oczko - przeżycia Amona i Holoubka mają to samo źródło: w obu wszedł „duch” („I wtedy Erzulie weszła we mnie. Zobaczyłem kapłana, którego teraz dosiadła Erzulie”) i obaj doznali transgresji, przekroczyli granice doświadczenia (Kolankiewicz, 1999, s. 220). Janion mówi wprost o Wielkiej Improwizacji jako o „ataku świętego opętania” (Kolankiewicz, 1999, s. 221).

\section{ZAKOŃCZENIE}

W filmie „Sztuka znikania” wszystko się ze sobą zazębia i łączy. Dlatego nie dziwi fakt, że reżyserzy wybrali na jego bohatera haitańskiego kapłana voodoo o polskich korzeniach. To ważne, bo jest to postać autentyczna, a przyleciał do Polski na zaproszenie Jerzego Grotowskiego, wielkiego człowieka teatru. Kolankiewicz uważa Grotowskiego za antropologa, który szukał dla teatru nowych źródeł i inspiracji: „,elem Grotowskiego nie była reforma teatru, lecz przemiana człowieka. Podobnie jak Mickiewicz, Grotowski szukał w sztuce teatru nowej antropologii, by ostatecznie porzucić sztukę” (Kolankiewicz, 1999, s. 224). Za antropologa uważany jest też Kapuściński. Wspólnym mianownikiem zaś jest w kontekście tych wszystkich nazwisk - przemiana człowieka w duchu antropologicznym.

Reżyserzy potraktowali fakty jako punkt wyjścia do opowiedzenia antropologicznej opowieści o ludzkiej egzystencji, zwłaszcza w jej obrzędowym i rytualnym wymiarze. Zdają się przez to mówić, że nie ma znaczenia ani odległość, ani kolor skóry, ani nawet cywilizacyjny status, bo i tak łączy ludzi różnych kultur „obrzędowy rytm świętowań”. Kapuściński sparafrazowałby tę refleksję konstatacją, że wszyscy jesteśmy jedną ludzką rodziną.

Bartosz Konopka i Piotr Rosołowski w twórczy sposób wykorzystali odkrycie Marii Janion, która dostrzegła w polskiej kulturze (głównie w dziedzinie literatury) wyraźne tendencje do „powrotu romantyzmu i powrotu do romantyzmu” (Janion, 1980, s. 56). Janion konkluduje, że na przestrzeni dziesięcioleci tych powrotów było wiele, ale „zarazem odczuwa się nową jakość w naszym współczesnym powrocie do romantyzmu - zresztą każdy z nich był inny. Nie sposób bowiem ani ponowić historycznego romantyzmu, ani powtórzyć któregoś z równie już historycznych powrotów do niego” (Janion, 1980, s. 57).

Konopka i Rosołowski znaleźli romantyzm, jakiego nikomu jeszcze nawet nie przyszło do głowy szukać! Niewątpliwie, romantyczny mesjanizm ubrany w voodooistyczny kontekst - to prawdziwa antropologiczna hydra, a Konopka 
i Rosołowski to zasłużeni dla antropologicznego myślenia „handlarze zdziwienia”. Bo jak chce Clifford Geertz:

\begin{abstract}
„W antropologii zawsze chodziło o przyglądanie się smokom, a nie o oswajanie ich czy budzenie do nich wstrętu, ani też o topienie ich w kadziach teorii [...] My, antropolodzy, zawsze staraliśmy się, z niemałym zresztą powodzeniem, nie dopuścić do równowagi w świecie - wyrywając sobie nawzajem pledy, przewracając stoliczki do herbaty, odpalając petardy. Domeną innych jest rozpraszanie wątpliwości, naszą ich wzbudzanie. Australopiteki, triksterzy, języki mlaskowe, megality - polujemy na anomalie, kramarczymy innością; my, handlarze zadziwienia”"
\end{abstract}

\title{
Bibliografia
}

Burszta, W.J., Kuligowski, W. (2005). Sequel. Dalsze przygody kultury w globalnym świecie. Warszawa: Warszawskie Wydawnictwo Muza SA.

Burszta, W.J. (2004). Różnorodność i tożsamość. Antropologia jako kulturowa refleksyjność. Poznań: Wydawnictwo Poznańskie.

Burszta, W.J. (1998). Antropologia kultury. Poznań: Zysk i S-ka.

Burszta, W.J., Piątkowski, K. (1994). O czym opowiada antropologiczna opowieść. Warszawa: Instytut Kultury.

Czermińska, M. (2003). „Punkt widzenia” jako kategoria antropologiczna i narracyjna w prozie niefikcjonalnej. Teksty Drugie, 2/3, s. 11-27.

Janion, M. (2007). Gorączka romantyczna. Gdańsk: Słowo/Obraz Terytoria.

Janion, M. (1980). Odnawianie znaczeń. Kraków: Wydawnictwo Literackie.

Kapuściński, R. (2003). Autoportret reportera. Kraków: Znak.

Kapuściński, R. (1998). Heban. Warszawa: Czytelnik.

Kapuściński, R. (1962). Busz po polsku. Warszawa: Czytelnik.

Karpowicz, I. (2007). Nowy kwiat cesarza (i pszczoły). Warszawa: Państwowy Instytut Wydawniczy.

Kolankiewicz, L. (2007). Samba z bogami. Opowieść antropologiczna. Warszawa: Wydawnictwo KR.

Kolankiewicz, L. (1999). Dziady. Teatr święta zmarłych. Gdańsk: Słowo/Obraz Terytoria.

Kołodziejczyk, D. (2002). Antropologiczne fabulacje - hybryda, tłumaczenie, przynależność we współczesnej powieści anglojęzycznej. W: W. Burszta, W. Kuligowski (red.), Ojczyzny słowa. Narracyjne wymiary kultury (63-98). Poznań: Biblioteka Telgte.

Kornak, M. (2010). Czarna Polonia, czyli o pierwszych polskich antyrasistach. Nigdy Więcej, 18, s. 1-3.

5 Cyt. za: W.J. Burszta (2004). Różnorodność i tożsamość. Antropologia jako kulturowa refleksyjność. Poznań: Wydawnictwo Poznańskie, s. 80-81. 
Lem, S. (1999). Bomba megabitowa. Kraków: Wydawnictwo Literackie.

Olszewska-Dyoniziak, B. (2001). Człowiek - kultura - osobowość. Wstęp do klasycznej antropologii kulturowej. Wrocław: Wydawnictwo Atla.

Przylipiak, M. (2000). Poetyka kina dokumentalnego. Gdańsk: Wydawnictwo Uniwersytetu Gdańskiego.

Raszewski, Z. (1991). Teatr w świecie widowisk. Warszawa: Wydawnictwo Krąg.

Turner, V. (2005). Proces rytualny. W: L. Kolankiewicz (red.), Antropologia widowisk. Zagadnienia i wybór tekstów (s. 121-138). Warszawa: Wydawnictwo Uniwersytetu Warszawskiego.

Zwoliński, A. (2011). Świat voodoo. Kraków: Wydawnictwo WAM. 